\title{
PENINGKATAN KEMANDIRIAN USAHA KECIL DAN MENENGAH MELALUI PENDAMPINGAN PROGRAM KKN-PPM
}

\author{
U.S.Y.V. Indrawati ${ }^{1}$, N. Endang ${ }^{2}$, N. Asriati ${ }^{3}$
}

\begin{abstract}
ABSTRAK
Sinar Billis dan Lina Sederhana adalah dua Kelompok Usaha yang bergerak di pembuatan ikan asin tipis dan merupakan target Program KKN-PPM, untuk meningkatkan diversifikasi produk olahan ikan, peningkatan kualitas produksi dengan teknologi perbaikan kemasan, pemasaran dengan sistem online. Tujuan kegiatan KKN- PPM adalah 1. Bagi Mahasiswa: a. Meningkatkan kemampuan dan ketrampilan mahasiswa untuk melakukan pengolahan ikan menjadi dendeng, abon dan ikan asap dan mampu berinteraksi dengan kelompok masyarakat nelayan, b. Mengatasi permasalahan di masyarakat melalui pemberdayaan masyarakat terutama kaum perempuan dan pemuda pengangguran dalam mengolah ikan menjadi dendeng, abon dan ikan asap 2. Bagi masyarakat: a. Meningkatkan ketrampilan dalam mengolah ikan menjadi dendeng, abon dan ikan asap, b. Peningkatan modal kerja dari bapak asuh usaha sebagai penyandang dana, c. Peningkatan jumlah dan kualitas produksi serta area pemasaran produk, Pelaksanaan kegiatan dimulai dengan pelatihan kepada mahasiswa peserta KKN membuat diversifikasi olahan ikan, pengemasan, dan pemasaran produk, dilanjutkan dengan diskusi dan sosialisasi kepada ketua Kelompok Usaha. Peserta kegiatan sangat bersemangat dalam mengikuti kegiatan yang diberikan. Ketua Kelompok Usaha sangat menyadari dengan adanya diversifikasi olahan ikan dan pembuatan label dan kemasan serta website akan menambah daya jual produk berbasis ikan, sehingga secara tidak langsung dapat meningkatkan perekonomian.
\end{abstract}

Kata kunci: diversifikasi, abon ikan, dendeng ikan, sale ikan, website

\begin{abstract}
Sinar Billis and Lina Sederhana are two Business Groups engaged in the manufacture of thin salted fish and are the target of KKN-PPM Program, to increase the diversification of processed fish products, improvement of production quality with packaging improvement technology, marketing with on line system. The purpose of KKN PPM activities are: 1. For Students: a. Improving ability and skill of students to make fish processing into jerky, abon and smoked fish and able to interact with fishermen community group, b. Overcoming problems in society through community empowerment especially women and youth unemployment in processing fish become jerky, abon and smoked fish 2. For society: a. Improving skills in processing fish into jerky, abon and smoked fish, b. Increased working capital from foster business as a funder, c. Increasing the quantity and quality of production and product marketing area. Implementation of the activities started with training for KKN students to diversify the processed fish, packaging, and product marketing, followed by discussion and socialization to the head of the Business Group. The participants were very excited to follow the activities. Chairman of the Business Group is very aware with the diversification of processed fish and label and packaging and web site will increase the selling power of fish-based products, so indirectly can improve the economy.
\end{abstract}

Keywords: diversification, fish abon, jerky fish, fish sale, website

${ }^{1}$ Fakultas Pertanian, Universitas Tanjungpura, HP 081352284012, E-mail: uraisuci@gmail.com

${ }^{2}$ Fakultas Fisipol, Universitas Tanjungpura, HP. 08125711773, E-mail: ngusmantofisipuntan@yahoo.com

${ }^{3}$ Fakultas IKIP, Universitas Tanjungpura, HP 085257515344, E-mail: nuraini_fkip@yahoo.co.id 


\section{PENDAHULUAN}

Sejalan dengan dicanangkannya Program Peningkatan Perekonomian Masyarakat Pesisir Pantai oleh Pemerintah Pusat, maka Kota "ikan" tengah diusung oleh Pemerintah Kubu Raya. Empat kecamatan pesisir seperti Sungai Raya, Sungai Kakap, Kubu dan Batu Ampar dipersiapkan sebagai kawasan penghasil ikan terbesar. Kedepan bisa menjadi daerah percontohan menyusul wilayah lain. (Dinas Perikanan dan Kelautan Kubu Raya, 2011).

Sebagian besar penduduknya hidup dari nelayan dan budidaya perikanan seperti pembuatan tambak dan keramba jaring apung (KJA) beserta keramba tancap. Menurut BPS, KKR Dalam Angka 2011, produksi perikanan di Desa Sungai Kakap pada tahun 2011 mengalami peningkatan sekitar 6,99 persen, yang terdiri dari 402,131ton produksi perikanan laut dengan biaya produksi Rp. Rp. 113.400.000,- dan tambak 1.089 ton dengan biaya produksi Rp. 48.300.000,-/ton. Sebagian besar, hasil dari keramba/tambak/tangkapan laut, hanya dijual dalam bentuk segar (freezer) dan diasinkan. Dari data yang didapat BPS, KKR Dalam Angka 2009, pemanfaatan potensi perikanan baru mencapai 40,11\% dari total produksinya. Dengan demikian, pemanfaatan potensi sumberdaya perikanan perlu ditingkatkan dengan melakukan diversifikasi terhadap hasil tangkapan.

Usaha mikro kecil menengah dianggap sangat strategis dan perlu perhatian khusus karena perkembangannya dalam membina lingkungan iklim usaha yang kondusif, memfasilitasi dan memberikan akses pada sumberdaya produktif dan memperkuat kewirausahaannya serta daya saingnya, dan salah satu caranya adalah dengan melakukan kemitraan. Untuk membangun kemitraan bisa dilakukan oleh Perguruan Tinggi yang menjembatani antara kelompok UUPKS dan BUMN/BUMNS sebagai bapak asuh dalam memfasilitasi penciptaam keserasian (match making).

Program Pembinaan Usaha Mikro, Kecil dan Menengah merupakan salah satu tanggungjawab sosial lingkungan yang bertujuan untuk mengembangkan kegiatan -kegiatan ekonomi masyarakat melalui pembinaan dan pendampingan serta program pinjaman dana bergulir kepada pengusaha-pengusaha local yang berpotensi untuk menggerakkan perekonomian daerah serta membuka peluang bagi masyarakat sekitar dalam meningkatkan taraf hidup masyarakat secara berkelanjutan. Hal-hal yang perlu mendapat pembinaan adalah bidang administrasi, ketrampilan industry dan ketrampilan pendukung.

Dengan memberikan pendampingan pengolahan ikan menjadi abon, dendeng dan ikan asap, diharapkan ikan akan lebih tahan lama, dengan tidak mengurangi nilai gizi dari ikan tersebut. Selain harga jual produk yang lebih tinggi dibandingkan dengan harga jual ikan segar, proses pembuatannya pun relative lebih mudah dan dengan biaya yang juga murah. Alat dan bahan yang dipergunakan mudah didapat , hanya saja proses pembuatannya yang belum familiar oleh masyarakat setempat.

Rendahnya tingkat pendidikan pengusaha UKM membawa dampak pada berbagai masalah antara lain: a. Kekurangmampuan akses dan perluasan pangsa pasar, b. Kekurangmampuan akses pada sumber-sumber pendanaan, c. Kekurangmampuan akses informasi, d. Kekurangmampuan memanfaatkan alih teknologi dan e. Kelemahan dalam pengelolaan informasi dan manajemen. Dalam hal ini UMKM cenderung mengembangkan bisnisnya dengan melakukannya sendiri sehingga tingkat produktivitasnya rendah bahkan tidak memperhatikan kualitas dan desain produknya. Dengan demikian jelas sangat mempengaruhi daya saing UKM di masa depan. Untuk menghasilkan UKM yang tangguh, maka peranan Perguruan Tinggi sangatlah penting, sehingga Program KKN-PPM dengan Program Pendampingan UKM berbasis UPPKS di Kecamatan Sungai Kakap, Kabupaten Kubu Raya perlu dilakukan dan melibatkan pihak Perguruan Tinggi.

\section{2 | BULETIN UDAYANA MENGABDI}


Program pendampingan ini sebagai tingkat kepedulian pihak akademis (mahasiswa dan dosen) untuk melakukan proses pembelajaran masyarakat dalam konteks pemberdayaan, yang datang untuk memfasilitasi (bukan menggurui), yang berada sejajar dengan masyarakat (bukan diatas masyarakat), yang berperan menemani masyarakat dalam melaksanakan setiap proses pemberdayaan.Kuliah Kerja Nyata merupakan kegiatan lapangan bagi mahasiswa yang sudah menyelesaikan 145 SKS dan akan menempuh bagian akhir pendidikan S1. Dengan belajar bersama masyarakat akan banyak hal yang diperoleh mahasiswa sebagai bekal di masa mendatang dalam memasuki dunia kerja.

\section{METODE PELAKSANAAN}

Dalam pelaksanaannya dibagi 2 kelompok kerja, dan mahasiswa KKN akan diberi penyuluhan dan praktek langsung cara pembuatan dendeng ikan, abon ikan dan ikan asap. Dari masing-masing UPPKS diterjunkan 10 orang mahasiswa untuk mentransfer teknologi pembuatan dendeng ikan manis, abon ikan dan ikan asap. Para mahasiswa dan peserta pelatihan diberi kesempatan untuk diskusi dan tanya jawab, dilanjutkan dengan demonstrasi dari masing-masing kegiatan, dan terakhir para peserta diberi kesempatan untuk langsung mempraktekkan dari masing masing kegiatan yang telah diberikan.

Setiap kegiatan yang diberikan sangat di respon dengan baik oleh peserta pelatihan, dan langsung dipraktekkan bersama dan dinikmati hasilnya. Setelah mahasiswa dan peserta pelatihan berhasil membuat satu produk olahan, maka mahasiswa akan menghitung biaya produksi dan keuntungan yang didapat apabila dipasarkan. Pada minggu terakhir, maka setiap kelompok mahasiswa membuat 2 tim pemasaran yang terdiri dari masing-masing kelompok 4 orang, dengan tujuan membantu pemasaran ke 3 produk olahan tersebut di Pontianak dan sekitarnya, baik melalui pameran-pameran, pergi ke mini market-mini market, restaurant-restauran, maupun ke kampus-kampus yang ada di Pontianak. Dari pihak dosen, membantu untuk membuat label produksi dan nomor produksi dengan mendaftarkan produk abon ikan (yang belum ada di Pontianak) di Dinas kesehatan, sebagai bukti bahwa abon ikan layak dipasarkan di Kalimantan Barat. Ketrampilan, ketelitian, keseriusan dan kemauan merupakan kunci utama dari keberhasilan pembuatan dendeng ikan, abon ikan dan ikan asap. Oleh karena itu, para peserta KKN terus diberi petunjuk, diberi semangat dan dicarikan jalan untuk memasarkan produk.

Kegiatan KKN bersama mahasiswa yang diberikan memberikan respon yang sangat positif, baik dari pihak Kecamatan maupun Kelurahan. Hal ini disebabkan karena selain dapat membantu pihak Kabupaten Kubu Raya dalam hal Pengolahan Pasca Panen Ikan, juga sangat membantu masyarakat yang tergolong ekonomi lemah dalam hal peningkatan pendapatan keluarga juga peningkatan pengetahuan dan ketrampilan. Dan harapan bagi pelaksana KKN, setelah kegiatan ini selesai dilaksanakan, akan ada atensi atau perhatian dari masing-masing instansi dinas terkait, untuk terus membina Kelompok Usaha yang sudah terbentuk, melalui Lembaga Pemberdayaan Masyarakat di Kelurahan, sehingga akan memberikan nilai yang positif dan nilai tambah bagi instansi yang terkait.

\section{HASIL DAN PEMBAHASAN}

Dalam kegiatan KKN PPM telah dilakukan kegiatan pembuatan abon ikan, dendeng ikan, ikan asap, pengemasan yang menarik, labeling, dan pemasaran via online. Pameran dilakukan pada akhir kegiatan. 


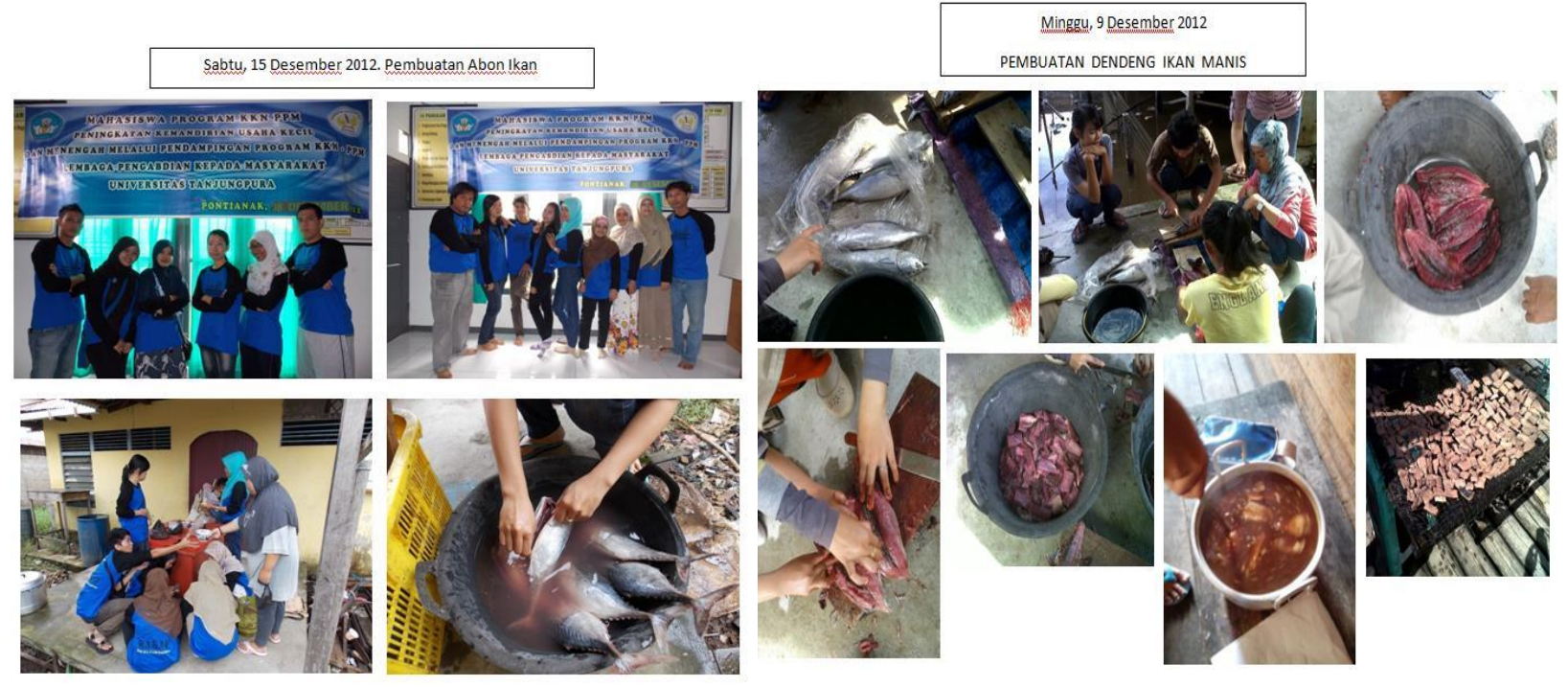

Gambar 1. Pembuatan abon dan dendeng ikan manis
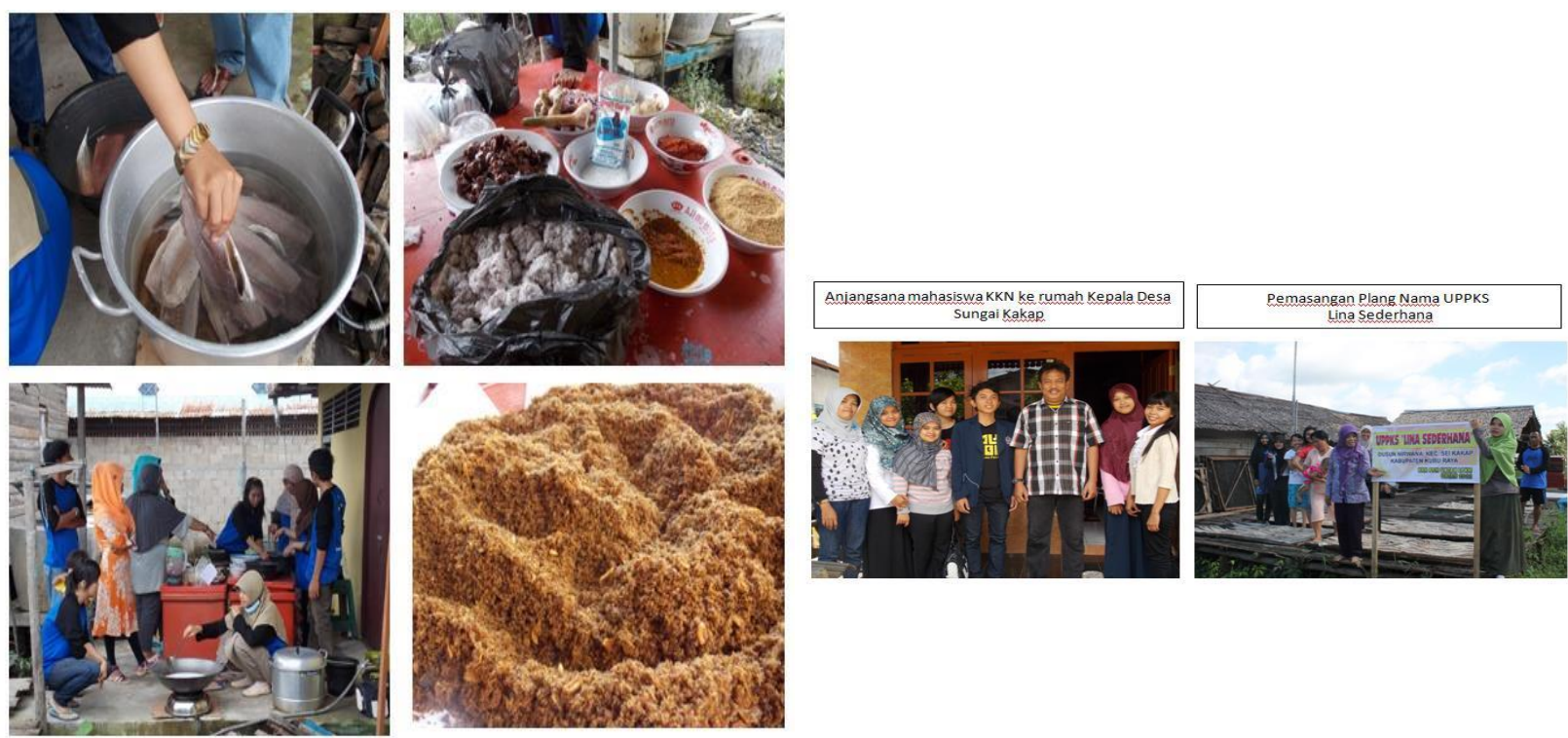

Gambar 2. Pembuatan abon ikan

PEMASANGAN PLANG UPPKS SINAR BILLIS

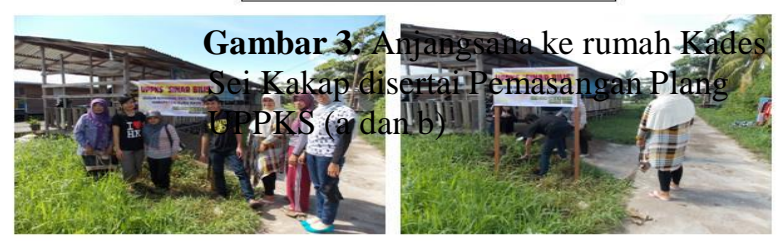




\section{KESIMPULAN}

Dari respon yang diperlihatkan oleh masyarakat pada saat melaksanakan kegiatan, dapat disimpulkan sebagai berikut :

1. Peserta KKN sangat antusias terhadap materi dan kegiatan yang diberikan berupa penyuluhan dan praktek tentang pembuatan dendeng, abon dan ikan asap, yang benar -benar dilaksanakan oleh mahasiswa sesuai petunjuk.

2. Kegiatan pembuatan produk, apabila dilaksanakan dengan serius dan teliti akan menghasilkan produk yang bernilai jual, sehingga dapat menambah pendapatan keluarga

\section{UCAPAN TERIMA KASIH}

Ucapan terimakasih disampaikan kepada Direktorat Penelitian dan Pengabdian kepada Masyarakat Dirjen DIKTI, Depdiknas dengan no DIPA 21/UN22.11/PM/2012 tanggal 6 November 2012.

\section{DAFTAR PUSTAKA}

Haryati Roebyantho, 2011, Dampak Sosial Ekonomi Program Penanganan Kemiskinan melalui KUBE, Jakarta; P3KS Press.

Muhammad Yusuf Stia, 2012, Peran UKM dalam Perekonomian Indonesia;
http://muhammadyusufstia.blogspot.com/2012/03/peran UKM dalam perekonomian Indonesia. (Selasa, 20 November 2012)

Rismaeka, 2011, UKM (Usaha Kecil Menengah) http://rismaeka.wordpress.com/2011/04/15/ukm-usaha-kecil menengah/ 